communication was obtained, the lighthouse keepers quickly learning how to use the apparatus. About this period, Marconi greatly increased the range of transmission by inserting the primary winding of a small air core transformer in the aerial, the secondary windings being split by a condenser, the outer ends being brought to the terminals of the coherer. These transformers were called 'jiggers', and their efficiency encouraged Marconi to attempt to communicate across the Channel. The French Government gave permission to erect a mast at Wimereux. A corresponding mast was erected at the South Foreland Lighthouse and Marconi successfully transmitted messages on March 27, 1899. The Wireless Co. had established their works at Chelmsford and had erected a mast 150 feet high. Communication was effected between this station and Wimereux-a distance of 85 miles.

In the year 1900 , the technical staff that the Wireless Co. had collected numbered only seventeen. Among them were Eccles, Erskine Murray and Andrew Gray, who was afterwards manager. In 1899, Prof. (now Sir Ambrose) Fleming had been appointed scientific adviser to the Company. The rapid increase in the range of radio communications had convinced Marconi that the curvature of the earth presented no obstacle to the extension of radio communication, and he decided to attempt to telegraph by his system across the Atlantic. In consultation with Fleming it was decided that the station for the transatlantic experiments should be built on the west coast of Cornwall. The site chosen was at Poldhu, on the west coast of the Lizard. In 1900, Marconi obtained his very important patent for 'tuned or syntonic telegraphy'. He used this method in his attempts to send signals across the Atlantic. $\mathrm{He}$ erected a station similar to Poldhu at Cape Cod in Mass., U.S.A. Unfortunately, the masts and aerial at Poldhu were wrecked by a storm, and a similar mishap at Cape Cod threatened to delay seriously the experiments. To save time when the Poldhu station was restored he went to Newfoundland and used a balloon to support his aerial. But as this was blown away, he used a kite as the support which, with great difficulty owing to a storm, was kept at a height of about 400 feet. He cabled to Poldhu to begin the pre-arranged programme, consisting of sending the Morse letter $\mathrm{S}$ ( 3 dots in succession) from 3 p.m. to 6 p.m. each day. On December 12 , 1901 , both he and his assistant repeatedly heard in their telephone the three clicks which proved that the electric waves had traversed the 1,800 miles separating St. John's from Poldhu.

In 1902, the site of a power station was chosen at Glace Bay in Canada, and when completed Marconi left England for Canada in an Italian cruiser, arriving on October 31, 1902. During the whole voyage he was receiving from Poldhu in the night time, but in the daytime he heard nothing after the distance was greater than 500 miles. When transmission was started, the early results were very disappointing. Later on, a site for a new station was found at Clifden, Ireland, and aerials were erected on a new principle Marconi had discovered. The Glace Bay and Clifden stations were opened for unlimited public service in February 1908. During the Irish rebellion, the Clifden Station was put out of action and a new station at Caernarvon in Wales was used instead.

Prior to 1916 it was generally accepted that for long-distance transmission long waves were essential. But in 1916 Marconi began his wonderful experiments on short-wave transmission, the wave-lengths being only about a hundredth of those usually employed. Erecting a small transmitting station at Poldhu, and fitting a receiver to his yacht Elettra, he found in 1923 that with a wave-length of 92 metres excellent reception could be obtained up to about 1,200 miles. The outcome of his work was that the Government accepted the Marconi Company's proposals to use the short-wave beam system for Imperial communications and started building stations capable of working with Canada, South Africa, India and Australia. Later on, in 1931, Marconi turned his attention to the systematic investigation of waves only about one metre in length. Using these waves, a transmission system was put into successful operation between the Vatican City and the papal palace at Castel Gaudolfo.

To the end of his life Marconi retained the vigour of youth. His love for experimenting never waned, and he infected his colleagues with his enthusiasm. He worked hard and was very successful in applying his theories.

Marconi married in 1905 the Hon. Beatrice O'Brien, daughter of Lord Inchiquin, who had been lady-inwaiting to the Queen of Italy. The marriage was dissolved by decree granted at Fiume in 1924. In 1927 he married the Countess Bezzi-Scali of Rome. $\mathrm{He}$ had one son and two daughters by his first wife and one daughter by his second.

During his lifetime Marconi's achievements brought him many of the highest honours which nations can bestow. His name is a household word all over the world. The patience and equanimity with which he bore the disappointing results obtained by many of his early laborious experiments will be for all time an encouragement to young engineering physicists.

\section{Dr. H. H. Jeffcott}

Henry Homan JefFCOTT, who died on June 29, was born in Co. Donegal in the year 1877. In 1895 he entered Trinity College, Dublin, from the High School, Dublin, and had a very distinguished career there. In 1897 he obtained a senior exhibition at the final freshman examination, and in 1898 he was first mathematical scholar. In 1899 he graduated with a senior moderatorship in experimental science and a junior moderatorship in mathematics and a moderatorship prize. He spent the next year in London, and in 1900 returned to Trinity College and entered the Engineering School, where he obtained his engineering degree in 1902 with honours in all subjects. In the same year he won the McCullagh Prize for a treatise on the theory of elasticity.

Jeffcott spent the next few years in the shops of Armstrong Whitworth and Co., Ltd., and as assistant 
engineer with Siemens Brothers, and in 1905 went to the National Physical Laboratory and there became head of the Metrology Department. In 1910 he returned to Dublin as professor of engineering in the Royal College of Science for Ireland. In 1914 he became Dean of the College. During the Great War years his department was organized most successfully for the manufacture of munitions. In 1922 he received the degree of doctor of science of the University of Dublin. From 1918 until 1921 he was secretary to the Water Power Resources of Ireland Sub-Committee and took an active part in collaboration with Sir John P. Griffith, past president of the Institution of Civil Engineers, in the preparation of a scheme for the development of the water-power of the River Liffey. This scheme, though put on one side while the power resources of the Shannon were being developed, is now beginning to take practical shape under the rgis of the Electricity Supply Board.

In 1922 Jeffcott left Dublin for London on his appointment as secretary to the Institution of Civil Engineers, which position he filled until his death. His charming manner endeared him alike to his staff and the members of the Institution. $\mathrm{He}$ was very approachable and welcomed members who called on him, especially those home from abroad. His business ability and tact combined to bring to a successful conclusion many important negotiations with Government departments and public authorities. The recent reorganization of the Institution's activities brought much work to Dr. Jeffeott which the state of his health made very onerous. His early death, on June 29 at the age of sixty years, will prove a severe loss to the Institution and an irreparable one to those who had the good fortune to be his friends.

Though of exceptionally fine physique-Jeffeott was well over six feet in height and broad in proportion-he never took an active part in the athletic life of his college, though he thoroughly enjoyed a good game of tennis.

Jeffcott achieved considerable success as an inventor, being best known in this connexion through the Jeffeott direct-reading tacheometer. He was the author of papers on the vibrations of loaded shafts published in the Proceedings of the Royal Society and Philosophical Magazine, and of papers on water resources and other engineering subjects.

\section{Miss Dorothy Sladden}

By the tragic death of Miss Sladden in consequence of a motor accident on Saturday, June 20, a severe blow was struck at the science of experimental zoology. Miss Sladden was one of those rare people on whom Nature has bestowed an inborn love of animals and a marvellous skill amounting to genius in keeping them in good health and in inducing them to breed. She had not had a university education, but she was taken to the Imperial College by her parents as an occasional student, because they saw no other outlet for her peculiar abilities which had manifested themselves since she was quite a young girl.
After passing through the regular undergraduate course, at my suggestion Miss Sladden took up the question of the heritability of acquired habit and carried out with indomitable perseverance a series of experiments on this subject which extended over five years. She showed that the stick-insect (Carausius morosus) which is a native of southern India but which has been imported into Great Britain and is readily obtainable from dealers, could be induced by a series of periods of semi-starvation to accept a food (ivy) which was at first repugnant to it, and that the offspring of such insects accepted ivy more readily than did their parents, so that after five or six generations, 100 per cent of the insects accepted ivy at the first opportunity. In this species, males occur only at long intervals and the ordinary female is parthenogenetic, so that the complications involved in crossing different stocks are completely avoided. Two of her papers on this subject had already been published by the Royal Society, and a third in which she dealt successfully with objections which had been made to her first two papers, was nearly ready when a cruel fate snatched her away. Fortunately, this paper will be completed by our mutual friend, $\mathrm{Mr}$. H. R. Hewer, who assisted and advised her in statistical matters.

It may be justly said that Miss Sladden has demonstrated beyond reasonable doubt that functional inheritance is a reality; and this is the cardinal question in zoology, indeed in all biology. Once this conviction has gone home, the whole course of evolution becomes clear and doctrines like the recapitulatory theory of evolution which have been fiercely fought over, follow as a matter of course. That functional inheritance must be true is a conclusion which had already been accepted by leading palæontologists and systematists in the British and other great museums, but the distaste for it felt by a certain modern school of biologists is so great that they refused to accept any but direct experimental evidence in its favour. This has now been provided by Miss Sladden, and it is a feat which will make her name live in the annals of zoology.

\section{E. W. MacBride.}

WE regret to announce the following deaths :

Prof. E. B. Elliott, F.R.S., emeritus professor of pure mathematics in the University of Oxford, on July 21, aged eighty-six years.

Prof. W. T. Mather, professor of physics in the University of Texas, on June 14, aged seventy-two years.

Major Paul Murphy, formerly director of experiments, Chemical Warfare Station, Porton, on July 14.

Prof. S. C. B. Pennington, emeritus professor of agriculture in the University of Reading, on July 19, aged sixty-eight years.

Sir Charles E. Saunders, formerly Dominion cerealist, known for his work on the breeding of wheat in Canada, on July 25, aged seventy years.

Prof. Johannes Walther, emeritus professor of geology and palæontology in the University of Halle, on May 3, aged seventy-seven years. 